\title{
Genetic Mapping of Quantitative Trait Loci for Yield-Affecting Traits in a Barley Doubled Haploid Population Derived from Clipper x Sahara 3771
}

\author{
Fatemeh Vafadar Shamasbi ${ }^{*}$, Seyed Hossein Jamali $^{2}$, Behzad Sadeghzadeh $^{3}$ and \\ Babak Abdollahi Mandoulakani ${ }^{4}$
}

'Department of Agricultural Biotechnology, Maragheh Branch, Islamic Azad University, Maragheh, Iran, ${ }^{2}$ Seed and Plant Certification and Registration Institute, Agricultural Research, Education and Extension Organization, Karaj, Iran, ${ }^{3}$ Dryland Agricultural Research Institute, Agricultural Research, Education and Extension Organization, Maragheh, Iran, ${ }^{4}$ Department of Plant Breeding and Biotechnology, Faculty of Agriculture, Urmia University, Urmia, Iran

\section{OPEN ACCESS}

Edited by:

Changbin Chen,

University of Minnesota,

United States

Reviewed by:

Liangran Zhang,

Shandong University, China

Yuguo Xiao,

Brigham Young University,

United States

*Correspondence:

Fatemeh Vafadar Shamasbi vafadar.u@gmail.com

Specialty section:

This article was submitted to Plant Genetics and Genomics,

a section of the journal

Frontiers in Plant Science

Received: 19 August 2016 Accepted: 13 April 2017 Published: 18 July 2017

Citation:

Vafadar Shamasbi F, Jamali SH,

Sadeghzadeh B and Abdollahi Mandoulakani B (2017) Genetic

Mapping of Quantitative Trait LoCi for Yield-Affecting Traits in a Barley Doubled Haploid Population Derived

from Clipper $\times$ Sahara 3771

Front. Plant Sci. 8:688.

do: $10.3389 /$ fpls.2017.00688
Many traits play essential roles in determining crop yield. Wide variation for morphological traits exists in Hordeum vulgare L., but the genetic basis of this morphological variation is largely unknown. To understand genetic basis controlling morphological traits affecting yield, a barley doubled haploid population (146 individuals) derived from Clipper $\times$ Sahara 3771 was used to map chromosome regions underlying days to awn appearance, plant height, fertile spike number, flag leaf length, spike length, harvest index, seed number per plant, thousands kernel weight, and grain yield. Twentyseven QTLs for nine traits were mapped to the barley genome that described 3-69\% of phenotypic variations; and some genomic regions harbor a given QTL for more than one trait. Out of 27 QTLs identified, 19 QTLs were novel. Chromosomal regions on $1 \mathrm{H}, 2 \mathrm{H}, 4 \mathrm{H}$, and $6 \mathrm{H}$ associated with seed grain yield, and chromosome regions on $2 \mathrm{H}$ and $6 \mathrm{H}$ had major effects on grain yield (GY). One major QTL for seed number per plant was flanked by marker VRS1-KSUF15 on chromosome $2 \mathrm{H}$. This QTL was also associated with GY. Some loci controlling thousands kernel weight (TKW), fertile spike number (FSN), and GY were the same. The major grain yield QTL detected on linkage PSR167 co-localized with TAM10. Two major QTLs controlling TKW and FSN were also mapped at this locus. Eight QTLs on chromosomes $1 \mathrm{H}, 2 \mathrm{H}, 3 \mathrm{H}, 4 \mathrm{H}, 5 \mathrm{H}, 6 \mathrm{H}$, and $7 \mathrm{H}$ consistently affected spike characteristics. One major QTL (ANIONT1A-TACMD) on 4H affected both spike length (SL) and spike number explained 9 and $5 \%$ of the variation of SL and FSN, respectively. In conclusion, this study could cast some light on the genetic basis of the studied pivotal traits. Moreover, fine mapping of the identified major effect markers may facilitate the application of molecular markers in barley breeding programs.

Keywords: barley (Hordeum vulgare L.), grain yield, linkage analysis, morphological traits, quantitative trait loci (QTL)

\section{INTRODUCTION}

Barley (Hordeum vulgare L.) is the fourth among cereal crops in grain production throughout the world (Asare et al., 2011; FAOSTAT, 2017). Barley is highly variable in utilization (i.e., animal feed, alcohol production, people food) and adaptation to marginal and subsistence environments. The principal focus of most commercial barley breeding programs has been on improving yield by 
developing new cultivars with high grain yield (GY) and high quality characteristics for different soils and climates (Arpaili and Yagmur, 2015).

In the process of crop improvement, determining the genetic basis of agronomic traits has been a scientific principle (Pasam et al., 2012). Most of the agronomical traits are quantitative and a number of genetic loci usually controls these traits (Ren et al., 2005). Quantitative trait loci (QTLs) mapping technology examine genetically many complex traits and QTL (Liu et al., 2015). This technology maps these loci with considering their positions in the genome and compares gene action, phenotypic effects, pleiotropic effects and epistasis interactions with other QTLs (Xiao et al., 1996; Zhu et al., 1999).

In barley, the identification of QTLs underlying main agronomic traits like GY (Thomas et al., 1998; Liu et al., 2015), malting quality (Borem et al., 1999; Beecher et al., 2001), disease resistance (Chen et al., 1994; Steffenson et al., 1996), drought tolerance (Mohammadi et al., 2005; Peighambari et al., 2005), and salt tolerance (Siahsar and Narouei, 2010; Aminfar et al., 2011) has been reported using molecular markers.

Up to now, limited information is available on the inheritance of morphological traits in doubled haploid (DH) population derived from Clipper $\times$ Sahara 3771. DH populations are very valuable material for genetic and molecular studies such as inheritance of quantitative traits, QTL mapping, genomics, gene identification, whole genome mapping due to less time requirement to make release of cultivars with desirable traits (Hussain et al., 2012). Genetic studies on the identification of loci controlling morphological variation show the complex genetic control of many quantitatively inherited traits in barley (Gyenis et al., 2007). The identification of QTLs associated with traits affecting yield is a significant starting point for transferring and pyramiding genes that can provide improvement of barley productivity (Sishen et al., 2007; Sadeghzadeh et al., 2015).

Heading date is a vitally important trait in adapting cereal species to drought conditions and maximizing yield potential (Bezant et al., 1996). Minimizing risk of lodging and increasing the harvest index (HI) can be controlled by plant height trait (Bezant et al., 1996). Heading date and plant height are influenced by many QTLs. Such traits usually exhibit complex inheritance involving multiple genes and environmental effect on trait development (Kjaer et al., 1995).

Spike morphology is related to GY because of its effects on grain number. Genetic gains in GY have historically been improved by changes in grain number per spike and spikes per square meter, with little change in individual grain weight. Hence, modifying the spike morphology to increase grain number may provide new opportunities for higher GY potential (Gaju et al., 2009; Zhou, 2015). In barley studies, the importance of flag leaf in determining GY has already been reported (Thorne, 1965; Yap and Harvey, 1972; Tungland et al., 1987; Zheng, 1999). Flag leaf could produce a large proportion of the carbohydrates stored in grains (Li et al., 1998). The morphological traits of flag leaf such as size and shape would be one of the best components in producing high GY (Hirota et al., 1990; Chen et al., 1995).

Ren et al. (2013) mapped the correlation QTL of agronomic and quality traits associated with GY in a DH population of barley. In another study, 16 QTLs associated with 3 morphological traits including flag leaf area, flag leaf length (FLL), and flag leaf width were identified in 2 years, which were located on chromosomes $2 \mathrm{H}, 3 \mathrm{H}, 4 \mathrm{H}$, and $7 \mathrm{H}$, respectively (Liu et al., 2015). Thousand kernel weight associated with directly the GY and quality of cereal crops, also with affecting on seedling vigor and growth, can indirectly affect GY (Wiersma et al., 2001; Botwright et al., 2002).

Genetic analyses have demonstrated close relationships between plant height, days to heading, FLL, spike length (SL), kernel weight with barley GY (Pasam et al., 2012); hence, our data may provide information for marker assisted selection (MAS) in barley breeding for high yield. The objective of this study was to determine the chromosomal location and phenotypic effects of QTLs associated with yield-affecting agro-morphological traits, GY and its component traits under controlled conditions. Molecular markers associated with QTLs identified would enhance progress in barley breeding programs for higher yield.

\section{MATERIALS AND METHODS}

The plant material used for the map construction and phenotyping was a $\mathrm{DH}$ population derived from a cross between the Australian cultivar 2-rowed Clipper (high yield) and Algerian 6-rowed Sahara 3771 (low yield landrace). The population was produced by the Hordeum bulbosum method (Finnie et al., 1989). The $\mathrm{DH}$ population and molecular data were kindly provided by the University of Western Australia. The measured traits were days from sowing to awn appearance (DAA), plant height (PLH), FLL, SL, fertile spike number per plant (FSN), seed number per plant (SN), thousands kernel weight (TKW), HI, and GY.

Twelve pre-germinated seeds from each DH line and their parents were sown under glasshouse conditions in soil surface of each plastic-lined pot. The experiment was carried out based on a randomized complete block design with two replications. Plants were grown in glasshouse at $25^{\circ} \mathrm{C}$ day $/ 15^{\circ} \mathrm{C}$ night temperature and $10 \mathrm{~h}$ natural sunlight photoperiod. The pots were filled with a poor sandy soil with $\mathrm{pH}$ 6. The pots were fertilized with basal nutrients (in $\mathrm{mg} / \mathrm{kg}$ of dry soil) 90 mono-potassium phosphate $\left(\mathrm{KH}_{2} \mathrm{PO}_{4}\right), 145$ potassium sulfate $\left(\mathrm{K}_{2} \mathrm{SO}_{4}\right), 20$ magnesium sulfate hepta-hydrate $\left(\mathrm{MgSO}_{4} .7 \mathrm{H}_{2} \mathrm{O}\right), 150$ calcium chloride dihydrate $\left(\mathrm{CaCl}_{2} \cdot 2 \mathrm{H}_{2} \mathrm{O}\right), 2$ copper sulfate pentahydrates $\left(\mathrm{CuSO}_{4} .5 \mathrm{H}_{2} \mathrm{O}\right), 0.7$ boric acid $\left(\mathrm{H}_{3} \mathrm{BO}_{3}\right), 15$ manganese sulfate monohydrate $\left(\mathrm{MnSO}_{4} \cdot \mathrm{H}_{2} \mathrm{O}\right), 0.8 \mathrm{mg} \mathrm{Zn} / \mathrm{kg}$ soil as zinc sulfate hepta-hydrate $\left(\mathrm{ZnSO}_{4} \cdot 7 \mathrm{H}_{2} \mathrm{O}\right), 0.2$ sodium molybdate dihydrate $\left(\mathrm{Na}_{2} \mathrm{MoO}_{4} \cdot 2 \mathrm{H}_{2} \mathrm{O}\right)$, and 93 ammonium nitrate $\left(\mathrm{NH}_{4} \mathrm{NO}_{3}\right)$. To minimize the effect of local microenvironment variation, the pots were rotated within a block daily. Plants were watered with double-deionized water daily by weight in glasshouse, keeping water content at $90 \%$ of the field capacity.

A genetic linkage map of 'Clipper' $\times$ 'Sahara 3771' population was developed by Karakousis et al. (2003). We mapped QTLs for the studied traits across the seven barley chromosomes using 335-restriction fragment length polymorphism (RFLP), simple sequence repeats (SSR) and morphological markers from this paper. QTL linkage mapping was performed using the software 
package QTL Network (Yang et al., 2007). To define individual adjacent QTL, we consider a minimum separation of $10 \mathrm{cM}$ ("filtration window").

Quantitative trait loci effects were simulated using Bayesian method of mixed linear model via Gibbs sampling (Sadeghzadeh et al., 2008). A $P$-value is obtained for each of the estimates of QTL effects by this analysis. A threshold of $P$-value less than 0.05 was considered as significance for QTL effect estimation. Correlation and QTL analyses were estimated for the data from each block (using Pearson's coefficient; two-tailed test), all data were analyzed to determine if there was a relationship between all the measured traits in the DH lines using SPSS software (Version 10; SPSS Inc., Chicago, IL, United States). Heritability was calculated for each trait using ANOVA analysis (using Version 10; SPSS Inc., Chicago, IL, United States software).

\section{RESULTS}

The frequency distributions of the measured traits have been shown in Figure 1. Analysis of variance revealed a significant difference among the DHs $(P<0.01)$ for the all measured traits (Table 1). Similar to DHs, the parental genotypes (Sahara 3771 and Clipper) were significantly different for all traits except HI. A wide range of variation was observed among $\mathrm{DHs}$ in the studied traits (Table 2 and Figure 1) and all traits approximately fit normal distributions, indicating the distribution expected for a polygenic and quantitatively inherited trait (Sadeghzadeh et al., 2010; Zhou, 2015). Phenotypic and genotyping coefficient of variation ranged from 8 to $34 \%$ and 7 to $32 \%$ in the DH population, respectively (Table 2). The environmental effects on all morphological traits, GY and its components were small, but the genotypic variance was large for all traits. The large heritability was estimated for SN (93\%), DAA (94\%), and TKW (97\%). Estimates heritability of the traits ranged from 67 to $97 \%$, indicating a high chance of detecting QTL for these traits by using a suitable linkage map.

A comprehensive molecular map of $\mathrm{DH}$ population enabled the identification of QTLs for morphological traits. Twenty-seven QTLs associated with the studied traits were detected on seven chromosomes (Table 3). Three QTLs based on mean value of trait were detected for DAA, PLH, FLL, and FSN traits.

Three QTLs was associated with DAA trait on chromosome $4 \mathrm{HS}, 5 \mathrm{HL}$, and $7 \mathrm{HL}$ and could totally explain $44 \%$ phenotyping variation for this trait (Table 3). The more effective QTL (qDAA-2) was flanked by RFLP marker ABG702 and SSR marker GBMS141 on chromosome 5HL. The chromosomal region close to marker GBMS141 was reported for controlling time to anthesis (Hussain et al., 2016). DAA was increased in DHs when alleles from Sahara 3771 were present at the identified QTLs. Sahara 3771 reached DAA later than Clipper $(23 \pm 4.5$ days after sowing).

For PLH, majority of DHs were taller than the parents and ranged from 45 to 66 centimeter (Table 2 and Figure 1). Three QTL for PLH were identified on chromosomes 3, 4, and 5 that could explain $45 \%$ of total variation for this trait (Table 3). Alleles that increased PLH at all three loci were derived from the parent Clipper that was 3 centimeters taller than Sahara 3771.

For SL, a significant variation was observed in DHs (ranged from 3.8 to $8.1 \mathrm{~cm}$ ), where SL for Clipper and Sahara 3771 were 7.4 and 5 centimeters, respectively. Six QTLs for SL were distributed on all barley chromosomes except $2 \mathrm{H}$ (Table 3). Half of the alleles increasing SL at the loci on $1 \mathrm{H}, 3 \mathrm{H}$, and $7 \mathrm{H}$ were contributed by Clipper, and explaining $25 \%$ of the phenotypic variance. The second QTL (qSL-2) flanked RFLP markers WG405 and HvGsl8 on 3HL could explain 16\% of the phenotypic variation. Although, the correlation between PLH and SL was significant and positive $\left(r=0.37^{* *}\right)$, but there was no common QTL between these traits (Table 4).

Three QTLs underlying FLL were found on $1 \mathrm{H}, 3 \mathrm{H}$, and $4 \mathrm{H}$. The QTL, qFLL-1 nearby RFLP marker CDO105 and SSR marker HVUXS2 accounted for 14\% phenotypic variation. The qFLL-2 mapped on $3 \mathrm{H}$ accounted for $13 \%$ phenotypic variation. The additional regions, qFLL-3 were also identified to be associated with FLL trait on $4 \mathrm{H}$ flanked by CDO1312 and CDO63 markers (Table 3). All three alleles increasing FLL were from Sahara 3771 that had 10 centimeters larger flag leaf compared with Clipper.

Three QTLs for FSN were mapped on $2 \mathrm{H}, 4 \mathrm{H}$, and $6 \mathrm{H}$ (Table 3), explaining 63\% of the phenotypic variance. All alleles increasing FSN were contributed by Clipper that had threefold more FSN than that Sahara 3771. Most of variance (46\%) in $\mathrm{SN}$ was controlled by qFSN-1 located on $2 \mathrm{HL}$ flanked by CDO474B-VRS1, and might be utilized in MAS in breeding for higher FSN per plant.

A significant differences was observed among the DHs for SN per plant (ranged from 15 to 62 with an average of 36 seeds per plant). Sahara 3771 (6-row barley) had nine more seeds per plant compared with Clipper (2-row barley). This variation in seed number is mainly due to high seed number of 6-row barley genotypes as compared to 2-row genotypes. In QTL analysis, one region was found to be associated with $\mathrm{SN}$ on $2 \mathrm{H}$ (VRS1-KSUF15), accounting for $67 \%$ of the total variation in SN trait.

Thousands kernel weight of DHs ranged from 24 to $54 \mathrm{~g}$, which shows significant variation among the DHs for seed size. TKW of Clipper and Sahara 3771 were 49 and $31 \mathrm{~g}$, respectively. The variation in distribution of seed size was mainly attributed to differences in spike row-type, with the 2-row plants (cv. Clipper-like) having significantly greater seed weight than the 6-row plants (Sahara 3771-like). QTLs associated with TKW were located on two different chromosomes $(2 \mathrm{H}$ and $6 \mathrm{H})$ that were contributed by Clipper alleles. In fact, most of TKW phenotypic variation (69\%) was controlled by qTKW-1 flanking by CDO474B-VRS-1 markers located on 2HL (Table 3).

The largest variation was found for HI among DHs (ranged from 25 to 60), where the both parents were similar for this trait (44.6 and $44.7 \%$ for Sahara 3771 and Clipper, respectively). Beneficial loci were donated from both parents, providing a good example of transgressive segregation for HI. Two QTLs were identified for $\mathrm{HI}$ on $1 \mathrm{H}$ and $2 \mathrm{H}$, explaining $44 \%$ of variation in HI. QTL on chromosome 2H was between CDO474B and VRS1 markers, and accounted for $38 \%$ of HI phenotypic variation. This QTL was also strongly associated with TKW (Table 3). 

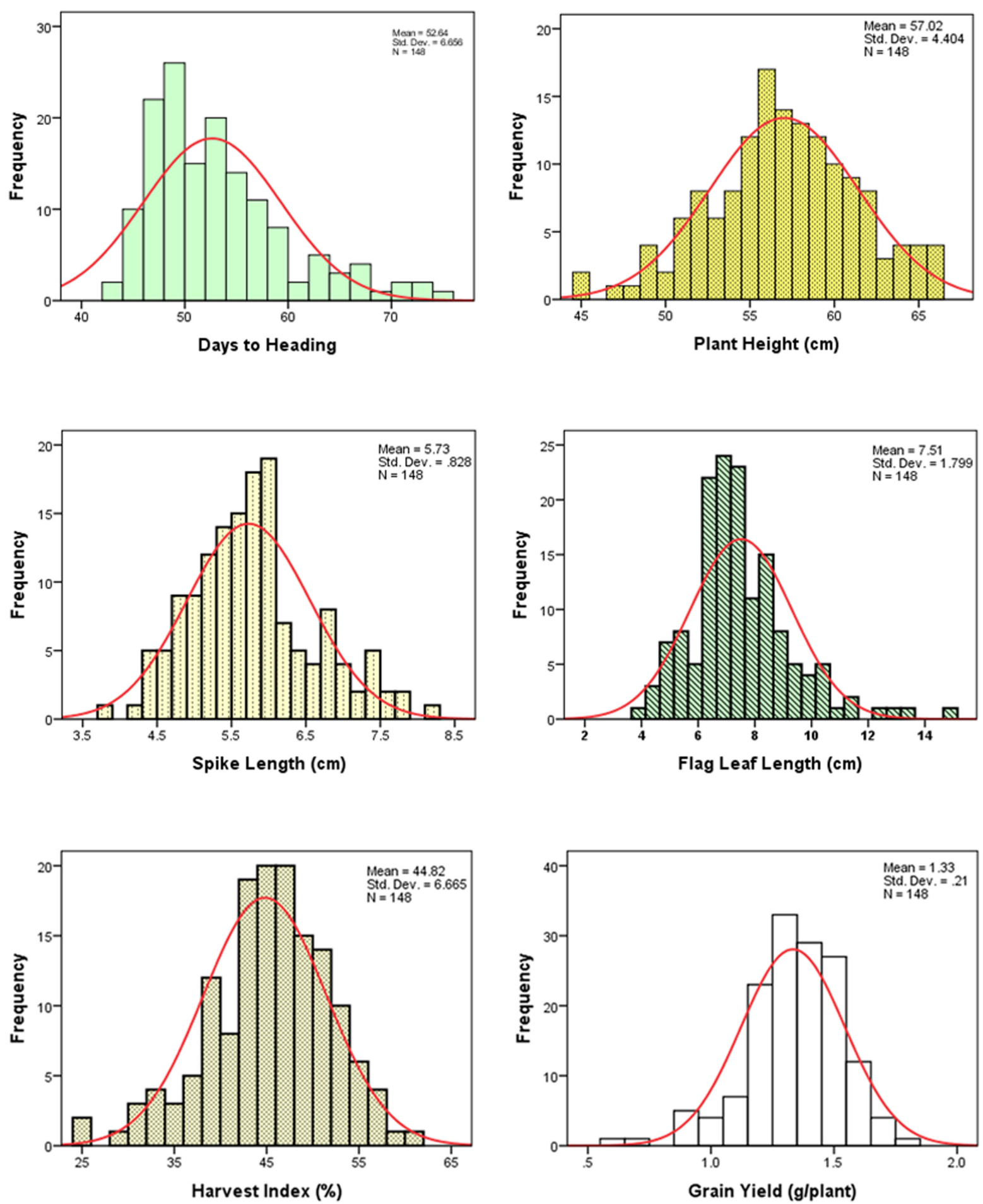

FIGURE 1 | Frequency distribution of the measured traits of 146 doubled haploid $(\mathrm{DH})$ lines derived from the Clipper $\times$ Sahara 3771 .

Grain yield was $50 \%$ higher in Clipper than Sahara 3771 and ranged from 0.4 to $1.8 \mathrm{~g} / \mathrm{plant}$ in DHs (Table 2 and Figure 2). Four QTLs associated with GY were detected on $1 \mathrm{H}, 2 \mathrm{H}, 4 \mathrm{H}$, and $6 \mathrm{H}$, controlling $38 \%$ of total variation of
GY (Table 3 and Figure 2). Of them, one QTL (qGY-1) was detected on chromosome $1 \mathrm{H}$, and accounted for $9 \%$ of phenotypic variation. The QTL located in interval VRS1KSUF15 on $2 \mathrm{HL}$ explained $14 \%$ of yield variation. This QTL 
was also tightly associated with $\mathrm{SN}$ per plant where there was positively significant correlation between GY and SN $\left(r=0.69^{* *}\right)$.

\section{DISCUSSION}

Quantitative trait loci mapping is an efficient method to analyze genetically complex traits and genotype-phenotype mapping (Chengsong et al., 2008). In barley, the correlation and QTLs of agronomic traits affecting GY in DHs derived from Clipper and Sahara 3771 had not been systematically analyzed. Desirable genetic variations for the measured traits in DHs was helpful in identification of the QTLs associated with the traits (Tables 2, 3). New methods in QTL mapping and more available sets of phenotypic data helped in detecting more and novel QTLs for the agronomic and yield component traits.

The DH lines on average were higher in PLH, FSN, and $\mathrm{SN}$ than the mean of the two parents, indicating the presence of additive $\times$ additive epistasis (Jui et al., 1997). There were significant correlations between DAA, FLL, SN, 6/2-row type, TKW, and HI with GY, but it is not known whether these correlations were due to linkages among QTLs or pleiotropy, or both. General heritability of most traits was above $85 \%$, indicating that screening for these traits would be effective (Table 2). SN per plant was positively correlated with GY, showing that SN may be a worthy screening criterion for better GY.

Twenty-seven QTLs were detected on all barley chromosomes. The number of significant QTL(s) per trait ranged from one to six (Table 3). In some traits with two or more significant QTLs detected, it can be inferred that both parents carry genes with alleles that increase or decrease phenotypic values (Xiao et al., 1996). Three overlapping QTLs of FS, TKW, and HI were identified on long arm of chromosome $2 \mathrm{H}$ flanking between CDO474B and VRS1 markers, explaining 46, 69, and 38\% of phenotypic variations for these traits, respectively. Alleles at this locus from higher fertile spike Clipper promoted greater TKW, where there is strong correlation between fertile spike and TKW $\left(r=0.58^{* *}\right)$. Marker VRS-1 controls 6/2 rowed-type in barley spike and confirms that 2-rowed plants have more fertile spike in comparison with 6-rowed plants (Komatsuda et al., 1999; Tanno et al., 2002). The existence of significantly negative correlation between 6-rowed spike and fertile spike $\left(r=-0.69^{* *}\right)$ supports the QTL analysis (Table 4). Meanwhile, fertile spike with 32\% genotypic coefficient variation had the highest value among the measured traits (Table 2). As expected, the major contributor to seed size was the 2-row locus (VRS1-KSUF15) on 2HL (originating from Clipper), which had a main controlling effect on seed weight (Table 3). This study also showed the existence of negatively large correlation $\left(r=-0.83^{* *}\right)$ between 6-row type and TKW (Table 4). Similar results were also reported for the role

TABLE 1 | Analysis of variance for yield and morphological traits in 146 barley doubled haploid (DH) lines.

\begin{tabular}{|c|c|c|c|c|c|c|c|c|c|c|}
\hline \multirow[t]{2}{*}{ sov } & \multirow[t]{2}{*}{$d f$} & \multicolumn{9}{|c|}{ Mean of square } \\
\hline & & $\begin{array}{l}\text { Days to awn } \\
\text { appearance }\end{array}$ & $\begin{array}{c}\text { Plant } \\
\text { height }\end{array}$ & $\begin{array}{l}\text { Spike } \\
\text { length }\end{array}$ & $\begin{array}{l}\text { Flag leaf } \\
\text { length }\end{array}$ & $\begin{array}{c}\text { Fertile } \\
\text { spike }\end{array}$ & $\begin{array}{c}\text { Seed } \\
\text { number }\end{array}$ & $\begin{array}{c}\text { Thousands } \\
\text { kernel }\end{array}$ & $\begin{array}{c}\text { Harvest } \\
\text { index }\end{array}$ & Grain yield \\
\hline Block & 1 & $325^{\text {ns }}$ & $151^{\mathrm{ns}}$ & $2.8^{\mathrm{ns}}$ & $12.5^{\mathrm{ns}}$ & $6.4^{\mathrm{ns}}$ & $565^{\mathrm{ns}}$ & $5.6^{\mathrm{ns}}$ & $231^{\mathrm{ns}}$ & $0.83^{\mathrm{ns}}$ \\
\hline Genotype & 145 & $8.5^{* *}$ & $39.7^{* *}$ & $1.4^{* *}$ & $5.7^{* *}$ & $1.21^{* *}$ & $188^{* *}$ & $108^{* *}$ & $90.7^{* *}$ & $0.09 * *$ \\
\hline Error & 145 & 5.30 & 5.31 & 0.29 & 1.90 & 0.12 & 12.57 & 3.29 & 8.99 & 0.01 \\
\hline Total & 291 & & & & & & & & & \\
\hline CV\% & & 4 & 4 & 9 & 19 & 15 & 10 & 5 & 7 & 9 \\
\hline
\end{tabular}

"*", "**", and "ns" are significant at the 0.05, 0.01 levels and non-significant, respectively.

TABLE 2 | The statistics of the 146 lines from DH population based on data from the Clipper $\times$ Sahara 3771 .

Trait
Parents

Sah Clip Range Mean LSD (5\%)

Doubled Haploid populations

$\begin{array}{cccc}\begin{array}{c}\text { Genotyping } \\ \text { coefficient of }\end{array} & \begin{array}{c}\text { Phenotyping } \\ \text { coefficient of }\end{array} & \begin{array}{c}\text { General } \\ \text { heritability }\end{array} & \begin{array}{c}\text { Genetic } \\ \text { advance \% }\end{array} \\ \text { variation (GCV)\% } & \text { variation (PCV)\% } & \left(\mathbf{h}^{2}\right) \% & \end{array}$

\begin{tabular}{lccccc}
\hline Days to awn appearance & 72 & 49 & $42-75$ & 52 & 4.5 \\
Plant height (cm) & 52 & 55 & $45-66$ & 57 & 4.6 \\
Spike length (cm) & 7.4 & 5 & $3.8-8.1$ & 5.7 & 1.1 \\
Flag leaf length & 15 & 5 & $3.9-13.4$ & 7.5 & 2.7 \\
Fertile spike & 1.0 & 3.3 & $1-3.8$ & 2.3 & 0.7 \\
Seed per plant & 38 & 29 & $15-62$ & 36 & 7.0 \\
Thousand kernel (g) & 31 & 49 & $24-54$ & 39 & 3.6 \\
Harvest index (\%) & 45 & 45 & $25-60$ & 45 & 5.9 \\
Grain yield (g/plant) & 1.1 & 1.5 & $0.4-1.8$ & 1.34 & 0.2
\end{tabular}


of 2-row locus (Vrs1) and seed size on Clipper $\times$ Sahara 3771 originated DH population (Lonergan et al., 2009; Sadeghzadeh et al., 2015).

For GY, co-localization of QTLs and related traits reported in previous studies (Quarrie et al., 2006; Gao et al., 2015). In the current study, QTL flanked by PSR167-TAM10 on $6 \mathrm{H}$ controlled FS, TKW, and GY traits (Table 3). Moreover, the interval 91-112 cM on long arm of 2H (VRS1-KSUF15) was a pleiotropic locus impacting $\mathrm{SN}$ and GY traits. No similar pleiotropic region on $2 \mathrm{HL}$ was previously reported. GY showed a significantly positive correlation with $\mathrm{SN}\left(r=0.69^{* *}\right)$. QTL contributed to VRS1-KSUF15 in this study had already been reported for GY increase (Hussain et al., 2016). Hence, the identified makers can be used for MAS to improve breeding

TABLE 3 | Quantitative trait loci (QTL) detected for morphological traits and yield based on data form 'Clipper' × 'Sahara 3771 ' 146 DH population.

\begin{tabular}{|c|c|c|c|c|c|c|c|}
\hline Trait & $\mathrm{QTL}^{\mathrm{a}}$ & Ch. & Flanking markers & Size (Mega-base) & $\begin{array}{l}\text { Interval QTL } \\
\text { position }(\mathrm{cM})^{\mathrm{b}}\end{array}$ & Additive effect ${ }^{c}$ & $\begin{array}{c}\text { Explained } \\
\text { variance (\%) }\end{array}$ \\
\hline \multirow[t]{3}{*}{ Days to awn appearance (DAA) } & qDAA-1 & $4 \mathrm{H}$ & ABC305A-HVGLYT5 & 188.9 & $114.6-121.9$ & $\mathrm{~S} 2.7^{* * *}$ & 10 \\
\hline & qDAA-2 & $5 \mathrm{H}$ & ABG702-GBMS141 & 171.6 & $108.3-120.3$ & S $4.5^{* * *}$ & 33 \\
\hline & qDAA-3 & $7 \mathrm{H}$ & ABC152D-AWBMA12A & 86 & $52.9-64.5$ & C $1.99^{* * *}$ & 11 \\
\hline \multirow[t]{3}{*}{ Plant height (PLH) } & qPLH-1 & $3 \mathrm{H}$ & WG178-HVM60 & 108.5 & $60-73.9$ & C $1.62^{* * *}$ & 17 \\
\hline & qPLH-2 & $4 \mathrm{H}$ & BCD808C-HVKNOX3 & 52.9 & $29.7-44.3$ & C $1.53^{* * *}$ & 17 \\
\hline & qPLH-3 & $5 \mathrm{H}$ & KSUA3A-ABC164 & 42 & $21.9-32.9$ & C $1.36^{* * *}$ & 11 \\
\hline \multirow[t]{6}{*}{ Spike length (SL) } & qSL-1 & $1 \mathrm{H}$ & ABG74-WG789D & 54.3 & $33.9-56.1$ & C $0.16^{* * *}$ & 3 \\
\hline & qSL-2 & $3 \mathrm{H}$ & WG405-HVGSL8 & 79.6 & $43-53.4$ & C $0.4^{* * *}$ & 16 \\
\hline & qSL-3 & $4 \mathrm{H}$ & ANIONT1A-TACMD & 143.7 & $86-96.7$ & $\mathrm{~S} 0.26^{* * *}$ & 9 \\
\hline & qSL-4 & $5 \mathrm{H}$ & ABG702-GBMS141 & 170.1 & $99.3-121.9$ & S $0.23^{* * *}$ & 7 \\
\hline & qSL-5 & $6 \mathrm{H}$ & EBMAC787-GBMS180 & 117.9 & $60.1-79.5$ & S $0.23^{* * *}$ & 9 \\
\hline & qSL-6 & $7 \mathrm{H}$ & WG789C-SSS1 & 47.4 & $20.1-42.9$ & C $0.20^{* * *}$ & 6 \\
\hline \multirow[t]{3}{*}{ Flag leaf length (FLL) } & qFLL-1 & $1 \mathrm{H}$ & CD0105-HVUXS2 & 71.1 & $57.1-64.9$ & S $0.66^{* * *}$ & 14 \\
\hline & qFLL-2 & $3 \mathrm{H}$ & BMAG6-EBMAC848 & 79.6 & $36-51.4$ & S $0.59 * * *$ & 13 \\
\hline & qFLL-3 & $4 \mathrm{H}$ & CD01312-CDO63 & 159.3 & $97.7-113.1$ & $\mathrm{~S} 0.62^{* * *}$ & 13 \\
\hline \multirow[t]{3}{*}{ Fertile spike number (FSN) } & qFSN-1 & $2 \mathrm{H}$ & CDO474B-VRS1 & 134.7 & $96.8-101$ & C $0.52^{* * *}$ & 46 \\
\hline & qFSN-2 & $4 \mathrm{H}$ & ANIONT1A-TACMD & 146.9 & $87-102.2$ & C $0.18^{* * *}$ & 5 \\
\hline & qFSN-3 & $6 \mathrm{H}$ & PSR167-TAM10 & 102.4 & $56.2-74.8$ & C $0.28^{* * *}$ & 12 \\
\hline Seed per plant (SN) & qSN-1 & $2 \mathrm{H}$ & VRS1-KSUF15 & 136.3 & $99.8-105$ & S $8.15^{* * *}$ & 67 \\
\hline \multirow[t]{2}{*}{ Thousand kernel weight (TKW) } & qTKW-1 & $2 \mathrm{H}$ & CDO474B-VRS1 & 133.4 & $96.8-101$ & C 6 $6^{* * *}$ & 69 \\
\hline & qTKW-2 & $6 \mathrm{H}$ & PSR167-TAM10 & 105.6 & $50.2-76.5$ & C $1.3^{* * *}$ & 4 \\
\hline \multirow[t]{2}{*}{ Harvest index (HI) } & $\mathrm{qH}-1$ & $1 \mathrm{H}$ & PSR158-CDO105 & 67.6 & $45.2-78.8$ & C $1.74^{* * *}$ & 6 \\
\hline & $\mathrm{qH}-2$ & $2 \mathrm{H}$ & CDO474B-VRS1 & 130.7 & $93.8-101$ & $\mathrm{~S} 4.42^{* * *}$ & 38 \\
\hline \multirow[t]{4}{*}{ Grain yield (GY) } & qGY-1 & $1 \mathrm{H}$ & BCD454-BMAC32 & 86.3 & $61.5-91$ & C $0.05^{* * *}$ & 9 \\
\hline & qGY-2 & $2 \mathrm{H}$ & VRS1-KSUF15 & 137.6 & $90.8-112.3$ & S $0.1^{* * *}$ & 14 \\
\hline & qGY-3 & $4 \mathrm{H}$ & CDO358-AWBMA29 & 80.1 & 46.9-56.3 & C $0.06^{* * *}$ & 3 \\
\hline & qGY-4 & $6 \mathrm{H}$ & PSR167-TMA10 & 99.2 & $56.2-69.4$ & C $0.09^{* * *}$ & 12 \\
\hline
\end{tabular}

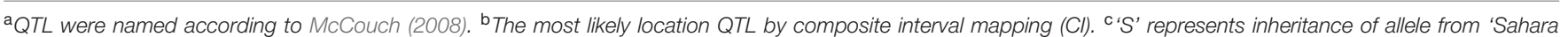
3771 ' and 'C' from Clipper parents. "***”" Indicates marker effect is statistically different from zero at $P<0.001$.

TABLE 4 | Phenotypic associations among the measured traits in DH lines based on Pearson correlation coefficient ( $r$ ).

\begin{tabular}{|c|c|c|c|c|c|c|c|c|c|}
\hline Trait & $\begin{array}{l}\text { Days to awn } \\
\text { appearance }\end{array}$ & $\begin{array}{l}\text { Plant } \\
\text { height }\end{array}$ & $\begin{array}{l}\text { Spike } \\
\text { length }\end{array}$ & $\begin{array}{l}\text { Flag leaf } \\
\text { length }\end{array}$ & $\begin{array}{l}\text { Fertile } \\
\text { spike }\end{array}$ & $\begin{array}{c}\text { Seed } \\
\text { number }\end{array}$ & $\begin{array}{l}\text { 6/2-row } \\
\text { type }\end{array}$ & $\begin{array}{c}\text { Thousand } \\
\text { kernel weight }\end{array}$ & $\begin{array}{l}\text { Harvest } \\
\text { index }\end{array}$ \\
\hline Plant height & -0.12 & & & & & & & & \\
\hline Spike length & $0.30^{* *}$ & $0.37^{* *}$ & & & & & & & \\
\hline Flag leaf length & $0.36^{* *}$ & -0.12 & 0.02 & & & & & & \\
\hline Fertile spike & $-0.32^{* *}$ & -0.10 & $-0.38^{* *}$ & $-0.27^{* *}$ & & & & & \\
\hline Seed number & -0.16 & -0.04 & 0.03 & $-0.30^{* *}$ & $-0.33^{* *}$ & & & & \\
\hline 6/2-row type & 0.08 & -0.09 & 0.09 & -0.04 & $-0.69^{* *}$ & $0.81^{* *}$ & & & \\
\hline Thousand kernel weight & -0.11 & 0.13 & -0.06 & 0.07 & $0.58^{* *}$ & $-0.78^{* *}$ & $-0.83^{* *}$ & & \\
\hline Harvest index & $-0.35^{* *}$ & 0.05 & 0.06 & $-0.35^{* *}$ & $-0.24^{* *}$ & $0.79^{* *}$ & $0.57^{* *}$ & $-0.40^{* *}$ & \\
\hline Grain yield & $-0.41^{* *}$ & 0.11 & 0.00 & $-0.41^{* *}$ & 0.13 & $0.69^{* *}$ & $0.34^{* *}$ & $-0.12^{* *}$ & $0.82^{* *}$ \\
\hline
\end{tabular}

"***" Correlation is significant at the 0.01 level (2-detail). 


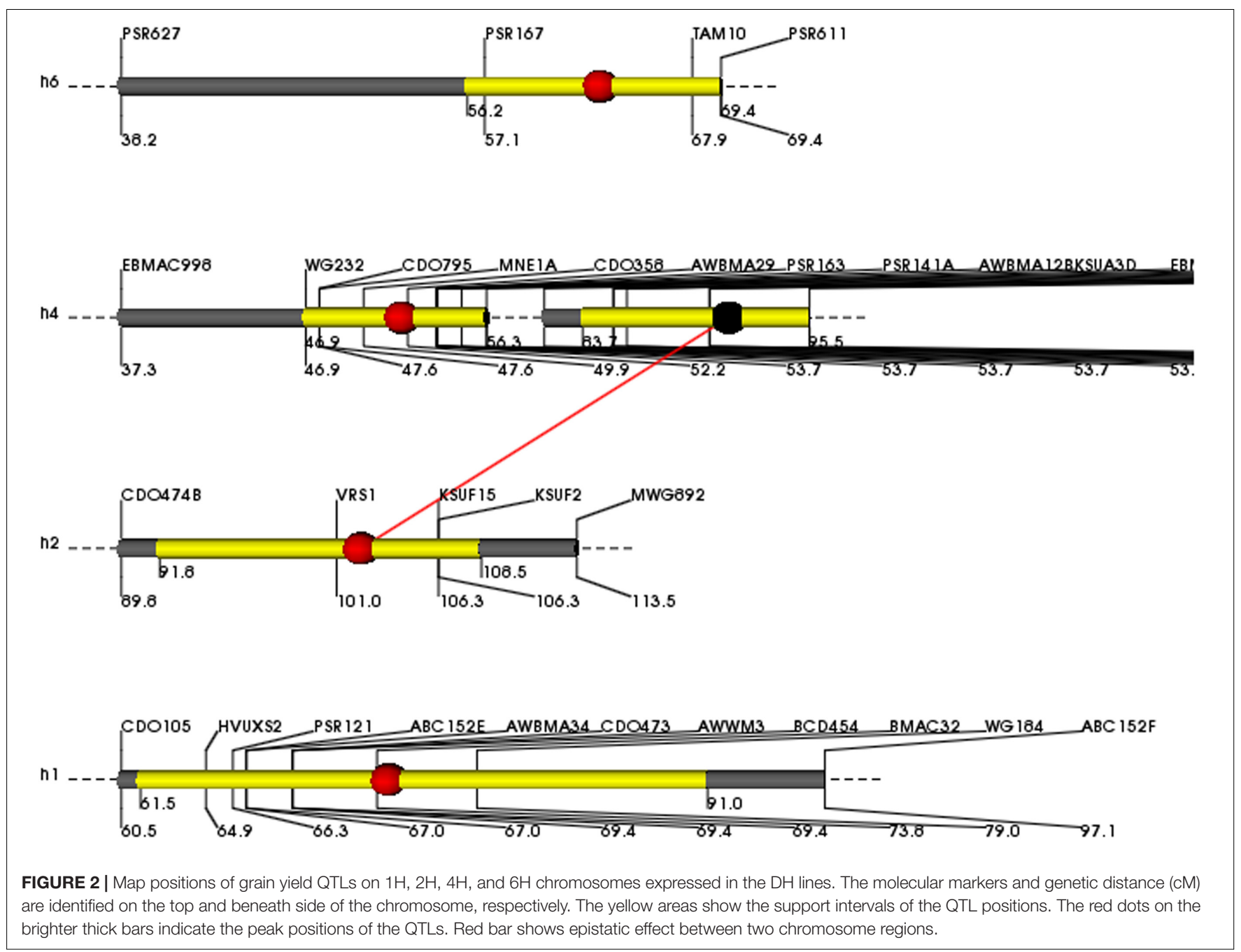

efficiency. In some studies, this chromosome region (VRS1KSUF15) was mapped on chromosome $2 \mathrm{HL}$ as controlling seed Zn content (Lonergan et al., 2009; Sadeghzadeh et al., 2015). We found that the identified region affected SN per plant, HI and GY. These data confirm efficiency of this chromosomal region to the fine mapping of these traits. Identified QTLs in glasshouse conditions, suggesting their value in marker-assisted selection. However, the assessment in field conditions were not performed in this $\mathrm{DH}$ population will be important for obtaining an inclusive view of breeding potential for these traits in barley in natural conditions to extend this research to other main crops.

\section{CONCLUSION}

The existence of great genotypic variations for the measured traits in Clipper and Sahara 3771 as well as derived DH lines proved the efficiency of this population for dissecting genomic regions influencing agronomic traits and GY components. Under glasshouse growing conditions, 2-row lines (Clipper and Clipper type) had $52 \%$ less grain number than 6-row ones (Sahara 3771 and Sahara type); however, 6-row lines (Sahara 3771 and Sahara
3771 type) had $11 \%$ more GY than 2-row ones (Clipper and Clipper type). The 6-row lines, however, were associated with low FS and low seed weight. Out of 27 QTLs associated with the interested traits in this study, the identified locus on the long arm of $2 \mathrm{H}$ chromosome controlling row type (Vrs1), FSN, SN per plant, TKW, HI, and GY, may facilitate the utilization of molecular markers in MAS in barley breeding programs for improved yield and yield components.

\section{AUTHOR CONTRIBUTIONS}

FVS, the corresponding author of the manuscript. Substantial contributions: design of the work, analysis and interpretation of data for the work and drafting the article. Agreement to be accountable for all aspects of the work in ensuring that questions related to the accuracy or integrity of any part of the work are appropriately investigated and resolved. SHJ design of the work, analysis, drafting the work or revising it critically for important intellectual content, final approval of the version to be published. BS: design of the work; or the acquisition, analysis, final approval of the version to be published. Agreement to be accountable for 
all aspects of the work in ensuring that questions related to the accuracy or integrity of any part of the work are appropriately investigated and resolved. BAM: design of the

\section{REFERENCES}

Aminfar, Z., Siahsar, B. A., and Heidary, M. (2011). Determination of chromosomes controlling physiological traits associated to salt tolerance in barley in seedling stage. New. Biotechnol. 25:304. doi: 10.1016/j.nbt.2009.06.762

Arpaili, D., and Yagmur, M. (2015). The determination of selection criteria using path analysis in two rowed barley (Hordeum vulgare L. Conv. Distichon). Turk. J. Agric. Nat. Sci. 2, 248-255.

Asare, E. K., Jaiswal, S., Maley, J., Baga, M., Sammynaiken, R., Rossnagel, B. G., et al. (2011). Barley grain constituents, starch composition, and structure affect starch in vitro enzymatic hydrolysis. J. Agric. Food Chem. 59, 4743-4754. doi: $10.1021 / \mathrm{jf} 200054 \mathrm{e}$

Beecher, B., Smidansky, E. D., See, D., Blake, T. K., and Giroux, M. J. (2001). Mapping and sequence analysis of barley hordoindo lines. Theor. Appl. Genet. 102, 833-840. doi: 10.1007/s001220000488

Bezant, J., Laurie, D., Pratchett, N., Chojeckls, J., and Kearsey, M. (1996). Marker regression mapping of QTL controlling flowering time and plant height in a spring barley (Hordeum vulgare L.) cross. Heredity 77, 64-73. doi: 10.1038/hdy. 1996.109

Borem, A., Mather, D. E., Rosmusson, D. C., Fulcher, R. G., and Hayes, P. M. (1999). Mapping quantitative trait loci forstarch granule traits in barley. J. Crop. Sci. 29, 153-160.

Botwright, T. L., Condon, A. G., Rebetzke, G. J., and Richards, R. A. (2002). Field evaluation of early vigour for genetic improvement of grain yield in wheat. Crop Pasture Sci. 53, 1137-1145. doi: 10.1071/AR02007

Chen, F., Prehn, D., Hayes, P. M., Mulrooney, D., Corey, A., and Vivar, H. (1994). Mapping genes for resistance to barley stripe rust (Pucciniastriiformisf. sp. horde.). Theor. Appl. Genet. 88, 215-219. doi: 10.1007/BF00225900

Chen, W., Xu, Z., and Zhang, L. (1995). Physiological Bases of Super High Yield Breeding in Rice. Shenyang: Liaoning Science and Technology Publishing Company, 1-2.

Chengsong, Z., Michael, G., Buckler, E. S., and Yu, J. (2008). Status and prospects of association mapping in plants (review and interpretation). Plant Gen. 1, 5-20. doi: 10.3835 /plantgenome2008.02.0089

FAOSTAT (2017). Food and Agriculture Organization of the United Nations. Rome: FAOSTAT.

Finnie, S. J., Powell, W., and Dyer, A. F. (1989). The effect of carbohydrate composition and concentration on anther-culture response in barley (Hordeum vulgare L.). Plant Breed. 103, 110-118. doi: 10.1111/j.1439-0523.1989. tb00358.x

Gaju, O., Reynolds, M. P., Sparkes, D. L., and Foulkes, M. J. (2009). Relationships between large-spike phenotype, grain number, and yield potential in spring wheat. Crop Sci. 49, 961-973. doi: 10.2135/cropsci2008.05.0285

Gao, F., Wen, W., Liu, J., Rasheed, A., Yin, G., Xia, X., et al. (2015). Genome-wide linkage mapping of QTL for yield components, plant height and yield-related physiological traits in the Chinese wheat cross Zhou 8425B/Chinese Spring. Front. Plant. Sci. 6:1099. doi: 10.3389/fpls.2015.01099

Gyenis, L., Yun, S. J., Smith, K. P., Steffenson, B. J., Bossolini, E., Sanguineti, M. C., et al. (2007). Genetic architecture of quantitative trait loci associated with morphological and agronomic trait differences in a wild by cultivated barley cross. Genome 50, 714-723. doi: 10.1139/G07-054

Hirota, O., Oka, M., and Takeda, T. (1990). Sink activity estimation by sink size and dry matter increase during the ripening stage of barley (Hordeum vulgare) and rice (Oryza sativa). Ann. Bot. 65, 349-354. doi: 10.1093/oxfordjournals.aob. a087944

Hussain, B., Ahsan Khan, M., Ali, Q., and Shaukat, S. H. (2012). Why double haploid production is the best method for genetic improvement and genetic studies of wheat. IJAVMS 6, 216-228.

Hussain, S., Rengel, Z., Mohammadi, S. A., Ebadi-Segherloo, A., and Maqsood, M. A. (2016). Mapping QTL associated with remobilization of zinc from vegetative tissues into grains of barley (Hordeum vulgare). Plant Soil 399, 193-208. doi: 10.1007/s11104-015-2684-1 work, analysis, drafting the work or revising it critically for important intellectual content, final approval of the version to be published.

Jui, P., Choo, T., Ho, K., Konishi, T., and Martin, R. (1997). Genetic analysis of a two-row $\times$ six-row cross of barley using doubled-haploid lines. Theor. Appl. Genet. 94, 549-556. doi: 10.1007/s001220050450

Karakousis, A., Gustafson, J. P., Chalmers, K. J., Barr, A. R., and Langridge, P. (2003). A consensus map of barley integrating SSR, RFLP, and AFLP markers. Aust. J. Agric. Res. 54, 1173-1185. doi: 10.1071/AR02177

Kjaer, B., Jensen, J., and Giese, H. (1995). Quantitative trait loci for heading date and straw characters in barley. Genome 38, 1098-1104. doi: 10.1139/g95-146

Komatsuda, T., Li, W., Takaiwa, F., and Oka, S. (1999). High resolution map around the vrs1 locus controlling two- and six-rowed spike in barley, Hordeum vulgare. Genome 42, 248-253. doi: 10.1139/gen-42-2-248

Li, Z., Pinson, S. R. M., Stansel, J. W., and Paterson, A. H. (1998). Genetic dissection of the source-sink relationship affecting fecundity and yield in rice (Oryza sativa L.). Mol. Breed. 4, 419-426. doi: 10.1023/A:1009608128785

Liu, L., Sun, G., Ren, X., Li, C. H., and Sun, D. (2015). Identification of QTL underlying physiological and morphological traits of flag leaf in barley. BMC Genet. 16:29. doi: 10.1186/s12863-015-0187-y

Lonergan, P. F., Pallotta, M. A., Lorimer, M., Paull, J. G., Barker, S. J., and Graham, R. D. (2009). Multiple genetic loci for zinc uptake and distribution in barley (Hordeum vulgare). New Phytol. 184, 168-179. doi: 10.1111/j.1469-8137.2009. 02956.x

McCouch, S. R. (2008). Gene nomenclature system for rice. Rice 1, 72-84. doi: 10.1007/s12284-008-9004-9

Mohammadi, M., Taleei, A., Zeinali, H., Naghavi, M. R., Ceccarelli, S., Grando, S., et al. (2005). QTL analysis for phenology traits in doubled haploid population of barley. Int. J. Agric. Biol. 7, 820-823. doi: 10.1007/s00122-0162689-z

Pasam, R. K., Sharma, R., Malosetti, M., van Eeuwijk, F. A., Haseneyer, G., Kilian, B., et al. (2012). Genome-wide association studies for agronomical traits in a worldwide spring barley collection. BMC Plant Biol. 12:16. doi: 10.1186/ 1471-2229-12-16

Peighambari, S. A., Yazdi Samadi, B., Nabipour, A., Charmet, G., and Sarrafi, A. (2005). QTL analysis for agronomic traits in barley doubled haploids population grown in Iran. Plant Sci. 169, 1008-1013. doi: 10.1016/j.plantsci.2005. 05.018

Quarrie, S., Quarrie, S. P., Radosevic, R., Rancic, D., Kaminska, A., Barnes, J., et al. (2006). Dissecting a wheat QTL for yield present in a range of environments: from the QTL to candidate genes. J. Exp. Bot. 57, 2627-2637. doi: 10.1093/jxb/ erl026

Ren, X., Sun, D., Sun, G., Li, C., and Dong, W. (2013). Molecular detection of QTL for agronomic and quality traits in a doubled haploid barley population. Aust. J. Crop Sci. 7, 878-886.

Ren, Z. H., Gao, J. P., Li, L. G., Cai, X. L., Huang, W., Chao, D. Y., et al. (2005). A rice quantitative trait locus for salt tolerance encodes a sodium transporter. Nat. Genet. 37, 1141-1146. doi: 10.1038/ng1643

Sadeghzadeh, B., Rengel, Z., and Li, C. (2008). Mapping of Chromosome Regions Associated with Seed Zn Accumulation in Barley. Ph.D. thesis, The University of Western Australia, Perth, SA.

Sadeghzadeh, B., Rengel, Z., and Li, C. (2015). Quantitative trait loci (QTL) of seed zn accumulation in barley population Clipper $\times$ Sahara. J. Plant Nutr. 38, 1672-1684. doi: 10.1080/01904167.2014.991036

Sadeghzadeh, B., Rengel, Z., Li, C., and Yang, H. (2010). Molecular marker linked to a chromosome region regulating seed $\mathrm{Zn}$ accumulation in barley. Mol. Breed. 25, 167-177. doi: 10.1007/s11032-009-9317-4

Siahsar, B. A., and Narouei, M. (2010). Mapping QTLs physiological traits associated with salt tolerance in Steptoe $\times$ Morex doubled haploid lines of barley at seedling stage. J. Food Agric. Environ. 8, 751-759.

Sishen, L., Jizeng, J., Xianyun, W., Xiaocun, Z., Linzhi, L., Haimei, C., et al. (2007). A intervarietal genetic map and QTL analysis for yield traits in wheat. Mol. Breed. 20, 167-178. doi: 10.1007/s11032-007-9080-3

Steffenson, B. J., Hayes, P. M., and Kleinhofs, A. (1996). Genetics of seedling and adult plant resistance to net blotch (Pyrenophorateresf. sp. teres) and 
spot blotch (Cochliobolus sativus) in barley. Theor. Appl. Genet. 92, 552-558. doi: 10.1007/BF00224557

Tanno, K., Taketa, S., Takeda, K., and Komatsuda, T. (2002). A DNA marker closely linked to the vrs1 locus (row-type gene) indicates multiple origins of sixrowed cultivated barley (Hordeum vulgare L.). Theor. Appl. Genet. 104, 54-60. doi: 10.1007/s001220200006

Thomas, W. T. B., Baird, E., Fuller, J. D., Lawrence, P., Young, G. R., Russell, J., et al. (1998). Identification of a QTL decreasing yield in barley linked to Mlopowdery mildew resistance. Mol. Breed. 4, 381-393. doi: 10.1023/A:100964611 5967

Thorne, G. N. (1965). Photosynthesis of ears and flag leaves of wheat and barley. Ann. Bot. 29, 317-329. doi: 10.1093/oxfordjournals.aob.a083954

Tungland, L., Chapko, L. B., Wiersma, J. V., and Rasmusson, D. C. (1987). Effect of erect leaf angle on grain yield in barley. Crop Sci. 27, 37-40. doi: 10.2135/ cropsci1987.0011183X002700010009x

Wiersma, J. J., Busch, R. H., Fulcher, G. G., and Hareland, G. A. (2001). Recurrent selection for kernel weight in spring wheat. Crop Sci. 41, 999-1005. doi: 10.1007/ BF00272690

Xiao, J., Li, J., Yuan, L., and Tanksley, S. D. (1996). Identification of QTLs affecting traits of agronomic importance in a recombinant inbred population derived from a sub specific rice cross. Theor. Appl. Genet. 92, 230-244. doi: 10.1007/ BF00223380

Yang, J., Zhu, J., and Williams, R. W. (2007). Mapping the genetic architecture of complex traits in experimental populations. Bioinformatics. 23, 1527-1536. doi: 10.1093/bioinformatics/btm143
Yap, T. C., and Harvey, B. L. (1972). Relations between grain yield and photosynthetic parts above the flag leaf node in barley. Can. J. Plant Sci. 52, 241-246. doi: 10.4141/cjps72-037

Zheng, T. (1999). Effects of some photosynthetic organs on milking and grain yield of barley. Barley Sci. 1, 21-22.

Zhou, Y. (2015). Mapping Quantitative Trait Loci for Grain Yield and Yield Related Traits in a Hexaploid Winter Wheat Doubled Haploid Population. Dissertation for the degree of Doctor of Philosophy, University of Maryland, College Park, MD.

Zhu, H., Bricero, G., Dovel, R., Hayes, P. M., Liu, B. H., and Ullrich, S. E. (1999). Molecular breeding for grain yield in barley: an evaluation of QTL effects in a spring barley cross. Theor. Appl. Genet. 98, 772-779. doi: 10.1007/ s001220051134

Conflict of Interest Statement: The authors declare that the research was conducted in the absence of any commercial or financial relationships that could be construed as a potential conflict of interest.

Copyright (c) 2017 Vafadar Shamasbi, Jamali, Sadeghzadeh and Abdollahi Mandoulakani. This is an open-access article distributed under the terms of the Creative Commons Attribution License (CC BY). The use, distribution or reproduction in other forums is permitted, provided the original author(s) or licensor are credited and that the original publication in this journal is cited, in accordance with accepted academic practice. No use, distribution or reproduction is permitted which does not comply with these terms. 